\title{
SPECIES IDENTIFICATION, SLIME PRODUCTION AND OXACILLIN SUSCEPTIBILITY IN COAGULASE-NEGATIVE STAPHYLOCOCCI ISOLATED FROM NOSOCOMIAL SPECIMENS
}

\author{
Lucía E. Alcaráz*; Sara E. Satorres; Rodolfo M. Lucero; Olga N. Puig de Centorbi
}

Area Microbiología, Facultad de Química, Bioquímica y Farmacia, Universidad Nacional de San Luis, Argentina

Submitted: December 03, 2001; Returned to authors for corrections: June 13, 2002; Approved: February 20, 2003

\begin{abstract}
Ninety-two coagulase negative staphylococci (CNS) (forty-five of clinical origin and forty-seven of environmental origin), collected in a hospital in San Luis, Argentina, from March to June, 1999, were identified to species level by the ID 32 Staph and API Staph System (bioMérieux). Slime production was investigated by the quantitative and qualitative methods. Oxacillin susceptibility was determined by the disk diffusion test (1 $\mu \mathrm{g})$, the agar dilution method $(0.125$ to $4 \mathrm{mg} / \mathrm{ml})$ and agar screen $(6 \mu \mathrm{g} / \mathrm{ml})$. The presence of $m e c A$ gene was investigated by PCR. The clinical CNS species most commonly isolated were $S$. epidermidis, S. haemolyticus, S. hominis and S. saprophyticus. The frequency of slime production by clinical and environmental isolates was similar (25/45 and 27/47, respectively) and the results obtained by the quantitative and the qualitative methods correlated well. The mecA gene was detected in all S. epidermidis, S. haemolyticus and S. hominis isolates, which were resistant to oxacillin by the phenotypic methods. However, this gene was not present in S. klossii, S. equorum, S. xylosus and S. capitis strains. The gene was neither found in two out of the six $S$. saprophyticus isolates, in two out of three $S$. cohnii subsp. urealyticum isolates and in two out of five $S$. cohnii subsp. cohnii isolates, all of which resulted oxacillin resistant according to MIC. The gene was not found in oxacillin-susceptible strains either. Most of the CNS isolates (enviromental and clinical) that were slime producers were found to be oxacillin resistant, which makes the early detection of these microorganisms necessary to prevent their dissemination in hospitals, particularly among immunocompromised patients.
\end{abstract}

Key words: Coagulase-negative staphylococci, slime, mecA, oxacillin-R

\section{INTRODUCTION}

Coagulase-negative staphylococci (CNS) are ubiquitous microorganisms and predominate in normal skin flora. They are commonly isolated in clinical specimens and several species are recognized as important agents of nosocomial infections, especially in neonates, immunocompromised individuals and patients with internal prosthetic devices $(7,12,13,15)$. The origin of these infections can be endogenous or exogenous, coming from the hospital environment or from personnel hands. One critical factor for transmission of microorganisms from a person (patient or health care worker) to the environment and then to another person is the ability of these agents to survive on environmental surfaces (22). At the present time, CNS, especially S. epidermidis strains, represent the most frequent cause of nosocomial sepsis and they are the most common agents of infections associated with implanted medical devices (17).

Many strains of CNS form an adherent bacterial film, the slime, whose formation has been implicated as a factor of virulence. It is postulated that this is as a mechanism by which the bacterium adheres to and colonizes certain prosthetic devices. Several reports have shown that CNS produce enormous amounts of this extracellular substance during the growth on inert surfaces, allowing the adhesion of microorganisms to those surfaces. This adhesion is increased by the tissue fibronectin and plasma $(6,25)$. Recently, the genetic control of the slime

* Corresponding author: Area Microbiología. Facultad de Química, Bioquímica y Farmacia. Chacabuco y Pedernera. 5700, San Luis, Argentina. Fax: 54-02652 431301. E-mail: lucalca@unsl.edu.ar 
production has begun to be elucidated, first in S.epidermidis and then in S. aureus. Synthesis of the capsular polysaccharide is mediated by the ica operon (1).

Considering that the ability to produce extracellular slime in vitro has been proposed as a pathogenicity marker in CNS (2), being associated with the virulence of the organism (23), it is expected that environmental isolates do not frequently present such ability. Some investigators $(4,5,7)$ reported that CNS strains isolated from patients with clinically significant infections produced more slime than saprophytic strains.

Over the last decades, there has been an enormous increase and emergence of CNS strains resistant to the antibiotic methicillin, particularly in nosocomial settings (11). Most of these strains present the PBP 2 a- encoding $m e c A$, a penicillinbinding protein which has decreased affinity for $\beta$-lactams antibiotics. Others mechanisms associated with oxacillin (methicillin) resistance do not involve the $m e c A$ gene. These mechanisms may include hyperproduction of $\beta$-lactamase, production of penicillin-binding proteins other than PBP2a encoded by mecA, enzymes which inactivate methicillin or unknown mechanisms (3). Detection of resistance to oxacillin in staphylococci is important to guide the therapy and prevent the patient from being unnecessarily treated with vancomycin, which is an antimicrobial agent that presents therapeutic complications, high costs, and may lead to the selection of resistant mutants (19).

The purposes of this study were: 1) to identify to species level the different CNS strains isolated from a variety of environmental and clinical samples in a hospital in San Luis, Argentina; 2) to investigate the slime production, comparing different methods; 3 ) to evaluate the association between slime production and the origin and identity of the species; 4) to determine the susceptibility to oxacillin comparing the different methods and to relate these results with the slime production.

\section{MATERIALS AND METHODS}

\section{Bacterial isolates}

Staphylococcal isolates obtained during the period of March to June, 1999 from clinical and environmental specimens in a hospital in San Luis, Argentina, were tested. Forty-seven hospital environmental isolates resulted from the processing of 210 samples of different environments, beds and hospital devices. Forty-five clinical CNS isolates, provided by the hospital laboratory, were obtained from culture of several specimens (14 isolated from blood, 13 from urine, 13 from catheters, 2 from prosthetic valves, 1 from neurospinal fluid [NSF] of a patient with prosthetic valve and 2 from wounds.)

The samples were identified by colony morphology in blood agar plates and manitol salt agar, Gram stain characteristics, catalase and coagulase tests and DNase activity (15).

\section{Species level identification}

All strains were identified by ID-32 Staph and API Staph Systems (bio Mérieux, Vitek, Inc, Hazelwood, Mo) according to the instructions of the manufacturers.

\section{Slime production}

The isolates were simultaneously examined by two methods:

(i) Qualitative method in tube. The technique described by Christensen et al. 1982 (4) was used. In brief, a loop of organisms from a blood agar plate was inoculated into a glass tube containing $5 \mathrm{ml}$ of trypticase soy broth (TSB) and incubated at $35^{\circ} \mathrm{C}$ for $48 \mathrm{~h}$. The cultures were aspirated, the tubes were washed twice with distilled water and then stained with $0.25 \%$ safranin. A continuous film on the surface of the glass tube was considered positive. The formation of a ring at the liquid-air interface was not considered indicative of slime production. The results were registered by semiquantitative form using an estimate grade of slime production as follows: strong $(+++)$, moderate $(++)$, weak $(+)$ absent $(0)$. Each test was interpreted by two independent observers.

(ii) Quantitative determination was carried out by the micromethod proposed by Pfaller et al., 1988 (26) using tissue culture plates of 96 flat-bottomed wells. Each well was filled with $0.2 \mathrm{ml}$ of $10^{5} \mathrm{CFU} / \mathrm{ml}$ of a bacterial suspension in TSB. After $48 \mathrm{~h}$ incubation in aerobiosis at $35^{\circ} \mathrm{C}$, the contents were aspirated and the plates were washed twice with saline phosphate-buffered ( $\mathrm{pH}$ 7.2). The wells were stained with $0.25 \%$ safranin for $30 \mathrm{~s}$. The plates were read in an enzymelinked immunosorbent assay (ELISA) reader (Benchmark Biorad) to $490 \mathrm{~nm}$. Sterile TSB was used as negative control. All the experiments were repeated at least twice and the samples were tested in quintuplicate; the values of optical density were then averaged. A three-grade scale was used to evaluate the strains slime producing ability: negative, ODs $<0.500 ;(+)$ ODs $0.500-1.500 ;(++)$ ODs $>1.500 . S$. epidermidis ATCC 35984 was used as positive control for slime production and S. epidermidis ATCC 12228 was used as negative control.

\section{Susceptibility to oxacillin}

Staphylococcus aureus ATCC 29213 and S. aureus ATCC 43300 were used as control organisms.

The following susceptibility testing methods were used:

MIC determinations. The MIC of oxacillin ( 0.125 to $4 \mathrm{mg}$ / liter) was determined by using agar dilution methods according to guidelines recommended by the National Committee for Clinical Laboratory Standards (NCCLS). The breakpoint for susceptibility was $<0.25 \mathrm{ug} / \mathrm{ml}$ (20). Oxacillin powder was obtained from Sigma-Aldrich Canada Ltd (Oakville, Ontario, Canada) 
Oxacillin salt agar screen. Mueller Hinton agar (MH agar) plates with $4 \%(\mathrm{w} / \mathrm{v}) \mathrm{NaCl}$ and $6 \mu \mathrm{g}$ of oxacillin per $\mathrm{ml}$ were inoculated by streaking each culture in three directions using a cotton swab dipped into a bacterial suspension with a turbidity equivalent to $0.5 \mathrm{McF}$ arland standard in TSB. As a control, the same medium containing $4 \% \mathrm{NaCl}$ without oxacillin was inoculated. Plates were incubated aerobically at $35^{\circ} \mathrm{C}$ and were read at $24 \mathrm{~h}$. Any growth was considered as a positive test result (20).

Disk diffusion test. Disk diffusion tests were performed as described by NCCLS (21) with 1 ug oxacillin disk and MH agar. The plates were incubated aerobically at $35^{\circ} \mathrm{C}$ and inhibition zone diameters were read at $24 \mathrm{~h}$. Any growth within $17 \mathrm{~mm}$-diameter zone around the disk was considered indicative of resistance.

Detection of the mecA gene by PCR. Bacterial DNA extraction: The growth of the cultures in $\mathrm{MH}$ agar plates in aerobiosis at $35^{\circ} \mathrm{C}$ for $24 \mathrm{~h}$ was suspended in $500 \mu 1$ of $10 \mathrm{mM}$ Tris-1mM EDTA ( $\mathrm{pH} 8$ ) and the turbidity was adjusted to a 1.0 Mc Farland standard. This suspension was preincubated with $15 \mu \mathrm{g}$ of lysostaphin and $10 \mu \mathrm{l}$ of $10 \%$ sodium dodecyl sulfate (SDS) to digest the bacterial cell wall. After incubation for $1 \mathrm{~h}$ at $37^{\circ} \mathrm{C}$, the suspension was heated for $10 \mathrm{~min}$ at $100^{\circ} \mathrm{C}$. Phenol $(500 \mu 1)$ saturated with $100 \mathrm{mM}$ Tris $(\mathrm{pH} 8)$ was added and the ingredients were gently mixed and centrifuged at $9,700 \mathrm{x} g$ for 20 min. The aqueous phase was collected, and an equal volume of chloroform-isoamyl alcohol (24:1) was added. After mixing and centrifuging at $9,700 \mathrm{xg}$ for $20 \mathrm{~min}$, ethanol (2.5:1, by volume) was added to the aqueous phase, and the mixture was placed at $-20^{\circ} \mathrm{C}$ for $24 \mathrm{~h}$. The precipitate was removed by centrifugation at $9,700 \times$ g $10 \mathrm{~min}$, rinsed with $70 \%$ ethanol, centrifuged again and dried at $37^{\circ} \mathrm{C}$. The dried DNA was resuspended in distilled water and used as a template for PCR.

DNA amplifications: The amplification were performed with the primers mecAl (5'-AAA ATC GAT GGT AAA GGT TGG C) and $m e c A 2$ (5'-AGT TCT GCA GTA CCG GAT TTG C) yielding a PCR product of $533 \mathrm{bp}$ (28). PCR reactions were performed using the method described by Jaffe et al. (11) with modifications. The reaction mixtures consisted of a reaction buffer $\left(50 \mathrm{mM} \mathrm{KCl}, 10 \mathrm{mM}\right.$ Tris- $\left.\mathrm{HCl}[\mathrm{pH} 9.0], 1.5 \mathrm{mM} \mathrm{MgCl}_{2}\right)$ in a total volume of $15 \mu \mathrm{l}$ containing $5 \mu \mathrm{l}$ of template DNA, $0.2 \mathrm{mM}$ of each deoxynucleotide triphosphate (dATP, dTTP, dGTP and $\mathrm{dCTP}), 1 \mu \mathrm{M}$ of each primer, and $2 \mathrm{U}$ of Taq DNA polymerase (Promega). DNA amplification was carried out in a Perkin-Elmer thermocycler with the following thermal cycling profile: initial denaturation at $94^{\circ} \mathrm{C}$ for $5 \mathrm{~min}$, followed by 35 cycles of amplification (denaturation at $94^{\circ} \mathrm{C}$ for $2 \mathrm{~min}$, annealing at $57^{\circ} \mathrm{C}$ for $2 \mathrm{~min}$ and extension at $72^{\circ} \mathrm{C}$ for $1 \mathrm{~min}$ ), ending with a final extension at $72^{\circ} \mathrm{C}$ for $7 \mathrm{~min}$. Eight microliters of PCR products were detected by electrophoresis using a $2 \%$ agarose gel during
$1 \mathrm{~h}$ at $80 \mathrm{~V}$. The bands were stained with ethidium bromide $(0.5$ $\mu \mathrm{g} / \mathrm{ml}$ ) and observed under UV light. Each run included a DNA marker (Promega, Madison. WI. U.S.A.) and the strains $S$. aureus 25923 and $S$. aureus 43330 as controls.

\section{RESULTS}

Forty-seven CNS isolates, obtained from hospital environments, were identified as follows: $S$. xylosus, 11 isolates; S. klossii, 9; S. sciuri, 8; S. conhii subsp. conhii, 5; S. conhii subsp. urealyticum, 4; S. hominis, 4; S. haemolyticus, 3; S. equorum, 1 ; S. warneri, 1 and S. epidermidis, 1, and from clinical samples: S. epidermidis, 21; S. haemolyticus, 8; S. hominis, 7, S. saprophyticus, 6; S. capitis, $1 ;$ S. warneri, 1 and $S$. lugdunensis, 1.

Table 1 shows the distribution and slime production in CNS strains isolated from different clinical materials. Slime production was detected in 25 (55.5\%) isolates. Among species, 12 (57.1\%) of S. epidermidis, 5 (83.33\%) of S. saprophyticus, 3 (42.85\%) of S. hominis, 3 (37.5\%) of S.haemolyticus, and S. capitis and S. warneri strains were slime producers. Table 2 shows the results of slime production by the different CNS species according to the qualitative method in tube and quantitative micromethod. In general the same number of slime-producing strains was obtained by both methods, except for a $S$. klossii ambiental strain and a $S$. warneri clinical strain, whose slime production, observed through the quantitative method, was not detected by the qualitative method. Some differences in the degree of positivity among the assayed methods were observed.

Table 1. Distribution and slime production in CNS strains isolated from clinical materials.

\begin{tabular}{|c|c|c|c|c|c|c|c|c|c|}
\hline \multirow[t]{2}{*}{ Clinical source } & \multirow{2}{*}{ 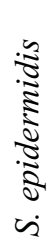 } & \multirow{2}{*}{ 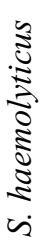 } & \multirow{2}{*}{ 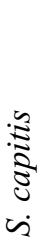 } & \multirow{2}{*}{ 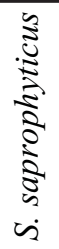 } & \multirow{2}{*}{ 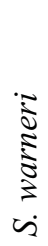 } & \multirow{2}{*}{ 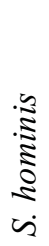 } & \multirow{2}{*}{ 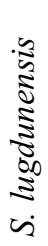 } & \multicolumn{2}{|c|}{ Total of strains } \\
\hline & & & & & & & & Tested & $\begin{array}{c}\text { Slime } \\
\text { positive }\end{array}$ \\
\hline Blood & 5 & 4 & 0 & 1 & 1 & 3 & 0 & 14 & $8^{a}$ \\
\hline Catheter & 11 & 0 & 1 & 1 & 0 & 0 & 0 & 13 & $9^{b}$ \\
\hline Prosthetic valve & 2 & 0 & 0 & 0 & 0 & 0 & 0 & 2 & $2^{c}$ \\
\hline Urine & 2 & 4 & 0 & 4 & 0 & 2 & 1 & 13 & $5^{\mathrm{d}}$ \\
\hline Neurospinal fluid & 1 & 0 & 0 & 0 & 0 & 0 & 0 & 1 & $1^{\mathrm{e}}$ \\
\hline Wounds & 0 & 0 & 0 & 0 & 0 & 2 & 0 & 2 & 0 \\
\hline Total & 21 & 8 & 1 & 6 & 1 & 7 & 1 & 45 & 25 \\
\hline
\end{tabular}

${ }^{a} S$. hominis 2, S. epidermidis 2, S. haemolyticus 3, $S$. saprophyticus $1 ;{ }^{\mathrm{b}}$ S. epidermidis 7, S. capitis 1, S. saprophyticus $1{ }^{\circ}$ S. epidermidis 2; d $S$. hominis $1, S$. lugdunensis $1, S$. saprophyticus 3 ; ${ }^{\mathrm{S}} \mathrm{S}$. epidermidis 1 . 
Table 2. Slime producer CNS strains according to qualitative and quantitative methods.

\begin{tabular}{|c|c|c|c|c|c|c|c|c|}
\hline \multirow{3}{*}{ Source and species } & \multirow{3}{*}{$\begin{array}{l}\text { No.of } \\
\text { strains }\end{array}$} & \multicolumn{6}{|c|}{$\begin{array}{l}\text { Slime production by } \\
\text { methods: }\end{array}$} & \multirow{3}{*}{$\begin{array}{l}\text { Total strains } \\
\text { slime-positive }\end{array}$} \\
\hline & & \multicolumn{3}{|c|}{ qualitative } & \multicolumn{3}{|c|}{ quantitative } & \\
\hline & & - & + & ++ & - & + & ++ & \\
\hline Environmental & 47 & & & & & & & \\
\hline S. xylosus & 11 & 7 & 4 & 0 & 7 & 4 & 0 & 4 \\
\hline S. klossii & 9 & 4 & 5 & 0 & 3 & 6 & 0 & 6 \\
\hline $\begin{array}{l}\text { S. conhii subsp. } \\
\text { urealyticum }\end{array}$ & 4 & 0 & 3 & 1 & 0 & 0 & 4 & 4 \\
\hline S. conhii subsp. cohnit & iii 5 & 0 & 3 & 2 & 0 & 3 & 2 & 5 \\
\hline S. sciuri & 8 & 5 & 2 & 1 & 5 & 1 & 2 & 3 \\
\hline S. haemolyticus & 3 & 2 & 1 & 0 & 2 & 1 & 0 & 1 \\
\hline S. hominis & 4 & 1 & 2 & 1 & 1 & 2 & 1 & 3 \\
\hline S. equorum & 1 & 1 & 0 & 0 & 1 & 0 & 0 & 0 \\
\hline S. warneri & 1 & 1 & 0 & 0 & 1 & 0 & 0 & 0 \\
\hline S. epidermidis & 1 & 0 & 1 & 0 & 0 & 1 & 0 & 1 \\
\hline Clinical & 45 & & & & & & & \\
\hline S. epidermidis & 21 & 9 & 8 & 4 & 9 & 7 & 5 & 12 \\
\hline S. haemolyticus & 8 & 5 & 3 & 0 & 5 & 3 & 0 & 3 \\
\hline S. capitis & 1 & 0 & 1 & 0 & 0 & 1 & 0 & 1 \\
\hline S. saprophyticus & 6 & 1 & 4 & 1 & 1 & 3 & 2 & 5 \\
\hline S. warneri & 1 & 1 & 0 & 0 & 0 & 1 & 0 & 1 \\
\hline S. hominis & 7 & 4 & 3 & 0 & 4 & 3 & 0 & 3 \\
\hline S. lugdunensis & 1 & 0 & 0 & 1 & 0 & 0 & 1 & 1 \\
\hline
\end{tabular}

$(-)$ negative; $(+)$ weak positive; $(++)$ moderate positive.
[7] and S. saprophyticus [6], a distribution similar to those found by other authors (13). S. capitis, $S$. warneri and S. lugdunensis were less frequent, althougth these strains have also been isolated from several clinical specimens $(10,13)$

Several environmental isolates, can be associated to a variety of human infections (14); as these isolates expand as nosocomial pathogens, they may produce serious infections, especially in immunocompromised patients. Isolates from the species S. klossii, S. xylosus, S. sciuri, and S. cohnii, presenting identical phenotypic characteristics, were isolated in different sectors of the hospital, which suggests a possible dissemination in the environment. The species identity was also correlated with the clinical significance of the isolates; the species $S$. epidermidis, $S$. hominis, $S$. haemolyticus and $S$. saprophyticus were more frequently found among the clinical samples than among the environmental samples $(21 / 1,7 / 4,8 / 3,6 /$ 0 , respectively).

On the other hand, slime production plays an important role in the pathogenesis of infections caused by different microorganisms, among them CNS. In relation to the distribution of slimeproducing species of clinical source, the results are similar to those reported by other authors $(8,27)$, who found that $S$. epidermidis frequently infects biomedical implants like intravascular catheters and prosthetic valves. It has also been reported $(4,24)$ that most of the isolates of this species from such

The results of the oxacillin susceptibility testing methods according to the disk diffusion test, oxacillin salt agar screen, MIC determination by agar dilution method and detection of $m e c A$ gene by PCR are shown in Table 3. Even though there was high coincidence among the phenotypic methods, a higher number of resistant strains was detected by MIC of oxacillin. Comparing the results obtained by these methods with the presence of the mecA gene, this gene was not found in any of the resistant strains of S. xylosus, S. klossii, S. equorum, and $S$. capitis. Considering only the resistant strains according to MIC of oxacillin, the mecA gene was not detected in two out of six $S$. saprophyticus, one out of three $S$. cohnii subsp. urealyticum and two out of five $S$. conhii subsp. cohnii. The gene was not found in susceptible strains. Table 4 shows slime production in oxacillin-resistant CNS strains.

\section{DISCUSSION}

The CNS clinical species most commonly isolated in this study were S. epidermidis [21], S. haemolyticus [8], S hominis devices produce a great quantity of extracellular mucoid substance or slime, which was also detected in this study.

In the present study, a similar frequency in slime production was detected in clinical isolates and in environmental isolates (25/45 and 27/47, respectively) (Table 4). This is surprising if we consider that slime production is a characteristic of CNS nosocomial pathogenic strains. In addition, this leads us to think that the environment could be the origin of the infections by these microorganisms.

Except for S. warneri and S. equorum, slime production was detected by both methods in all CNS species (Table 2). As in other studies (2), there was high coincidence in its detection by the quantitative and qualitative methods. It was also observed that some strains whose slime production was interpreted as $1+$ by the qualitative method presented an optical density $>1.500$, corresponding to $2+$ by the quantitative method.

Table 3 shows the correlation between the results of the phenotypic assays for the detection of oxacillin resistance and the presence of mecA gene. In general there was agreement between these results, especially in the most frequent species isolated from clinical samples: S. epidermidis, S. haemolyticus 
Table 3. Correlation between phenotypic methods for oxacillin resistance detection in CNS species and presence of $m e c A$ gene.

\begin{tabular}{|c|c|c|c|c|c|c|c|c|c|c|c|c|c|}
\hline \multirow{3}{*}{ Source and species } & \multirow{3}{*}{$\begin{array}{c}\text { Strains } \\
\text { tested }\end{array}$} & \multirow{2}{*}{\multicolumn{7}{|c|}{$\mathrm{N}^{\circ}$ of strains whose MIC was: }} & \multicolumn{5}{|c|}{$\mathrm{N}^{\circ}$ of strains } \\
\hline & & & & & & & & & \multicolumn{2}{|c|}{$\begin{array}{c}\text { Disk diffusion } \\
\text { test }\end{array}$} & \multicolumn{2}{|c|}{$\begin{array}{l}\text { Oxacillin salt } \\
\text { agar screen }\end{array}$} & \multirow[t]{2}{*}{$\begin{array}{c}\text { mecA gene } \\
\text { positive }\end{array}$} \\
\hline & & 0,125 & 0,25 & 0,5 & 1 & 2 & 4 & $>4$ & $\mathrm{~S}$ & $\mathrm{R}$ & $\mathrm{S}$ & $\overline{\mathrm{R}}$ & \\
\hline Environmental & 47 & & & & & & & & & & & & \\
\hline S. xylosus & 11 & 2 & 3 & 0 & 3 & 3 & 0 & 0 & 5 & 6 & 6 & 5 & 0 \\
\hline S. klossii & 9 & 0 & 1 & 0 & 0 & 8 & 0 & 0 & 1 & 8 & 1 & 8 & 0 \\
\hline S. cohnii subsp. urealyticum & 4 & 0 & 1 & 2 & 1 & 0 & 0 & 0 & 2 & 2 & 1 & 3 & 2 \\
\hline S. cohnii subsp. cohnii & 5 & 0 & 0 & 0 & 1 & 4 & 0 & 0 & 1 & 4 & 0 & 5 & 3 \\
\hline S. sciuri & 8 & 1 & 2 & 0 & 0 & 5 & 0 & 0 & 3 & 5 & 3 & 5 & 5 \\
\hline S. haemolyticus & 3 & 0 & 0 & 1 & 2 & 0 & 0 & 0 & 0 & 3 & 0 & 3 & 3 \\
\hline S. hominis & 4 & 0 & 1 & 0 & 2 & 1 & 0 & 0 & 1 & 3 & 2 & 2 & 3 \\
\hline S. equorum & 1 & 0 & 0 & 0 & 0 & 1 & 0 & 0 & 0 & 1 & 0 & 1 & 0 \\
\hline S. warneri & 1 & 0 & 0 & 0 & 0 & 1 & 0 & 0 & 0 & 1 & 0 & 1 & 1 \\
\hline S. epidermidis & 1 & 0 & 0 & 0 & 0 & 1 & 0 & 0 & 0 & 1 & 0 & 1 & 1 \\
\hline Clinical & 45 & & & & & & & & & & & & \\
\hline S. epidermidis & 21 & 0 & 4 & 2 & 5 & 10 & 0 & 0 & 5 & 16 & 4 & 17 & 17 \\
\hline S. haemolyticus & 8 & 0 & 3 & 1 & 0 & 4 & 0 & 0 & 3 & 5 & 3 & 5 & 5 \\
\hline S. capitis & 1 & 0 & 0 & 1 & 0 & 0 & 0 & 0 & 1 & 0 & 0 & 1 & 0 \\
\hline S. saprophyticus & 6 & 0 & 0 & 2 & 4 & 0 & 0 & 0 & 1 & 5 & 0 & 6 & 4 \\
\hline S. warneri & 1 & 0 & 1 & 0 & 0 & 0 & 0 & 0 & 1 & 0 & 1 & 0 & 0 \\
\hline S. hominis & 7 & 0 & 3 & 1 & 3 & 0 & 0 & 0 & 3 & 4 & 3 & 4 & 4 \\
\hline S. lugdunensis & 1 & 0 & 1 & 0 & 0 & 0 & 0 & 0 & 1 & 0 & 1 & 0 & 0 \\
\hline
\end{tabular}

S: susceptible; R: resistant.

Table 4. Correlation between susceptibility to oxacillin and slime production in CNS strains from clinical and environmental sources.

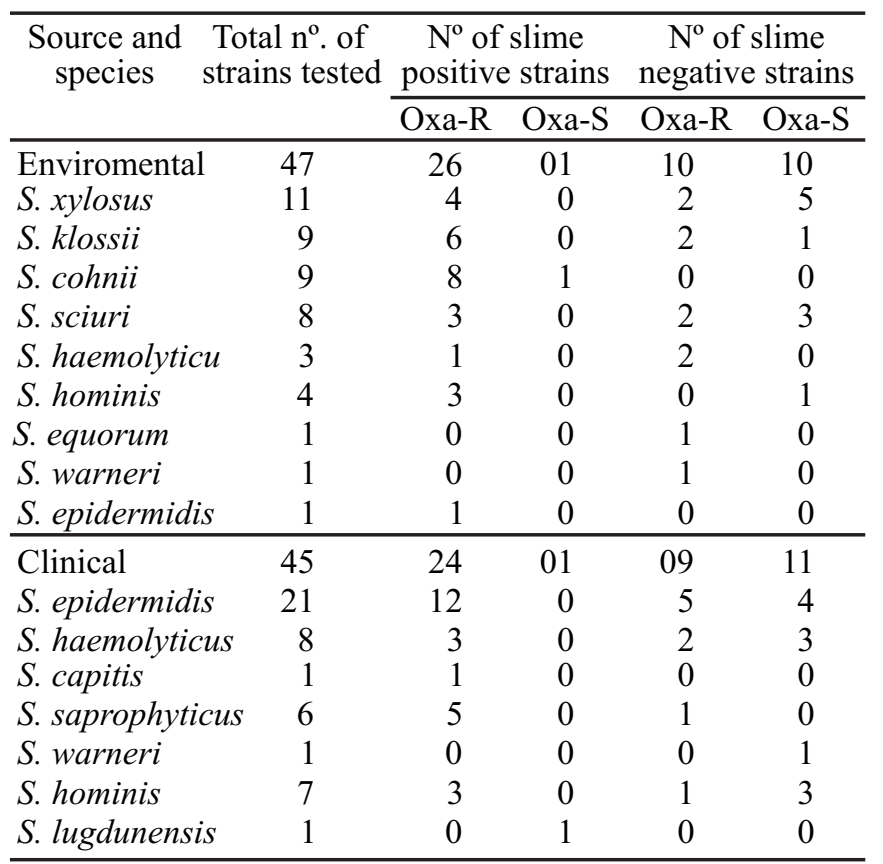

Oxa-R: oxacillin resistant; Oxa-S: oxacillin susceptible according to the presence of the mecA gene. and $S$. hominis. The mecA gene was not detected in two out of six $S$. saprophyticus isolates, in one out of three $S$. cohnii subsp. urealyticum isolates, and in two out of five $S$. cohnii subsp. cohnii isolates, all of which were found to be oxacillin resistant according to MIC. The gene was neither detected in S. xylosus, S. klosii, S. equorum and in the clinical isolate of $S$. capitis. Hussain et al. (9) reported high coincidence between the phenotypic methods and the presence of mecA gene, particularly in the species most commonly isolated in clinical laboratories, such as $S$. epidermidis, S. haemolyticus and S. hominis. Likewise, for the less frequent species, his results were not totally concordant, as occurred in the present study. Other authors have also reported differences, pointing out that some staphylococci strains lacking the mecA gene showed phenotypic resistance to oxacillin $(11,16)$. Deficiency of $m e c A$ gene in these species suggests a resistance mechanism different from $\mathrm{PBP} 2 \mathrm{a}$ production.

Table 4 shows a high resistance to oxacillin in both clinical and environmental strains (33/45 and 36/47 respectively). It also shows that most of the slime producing CNS isolates (environmental and clinical) were found to be oxacillin resistant. The 26 slime producer SCN environmental strains that were resistant to oxacillin were isolated in Pediatrics and Orthopaedics - Traumatology units, from the following surfaces and materials: floors and walls of the hospital rooms 
[6], stethoscopes [6], beds [9], tables for nursing elements [3], oxigen tube extreme [1], and oxigen mask [1]. These surfaces may play an important role in the spread of infectious agents including antimicrobial-resistant strains, so the regular use of disinfectant for their cleaning is advisable. It has been reported that the stethoscope can harbor potentially pathogenic bacteria (18). The early and precise detection of these microorganisms in hospital environments in order to control their dissemination can prevent the contamination of prosthetic devices and possible infections, especially among immunocompromised patients.

\section{RESUMO
Identificação de espécies, produção de "slime" e sensibilidade a oxacilina em amostras de Staphylococcus coagulase-negativo isoladas de espécimes nosocomiais

Noventa e duas amostras de Staphylococcus coagulase negativo ( $\mathrm{SCN}),(45$ amostras clínicas e 47 ambientais), coletadas em um hospital de San Luis, Argentina, durante o período de março a junho de 1999, foram identificadas até espécies, empregando-se os sistemas ID 32 Staph e API Staph (bioMérieux). A produção de "slime" foi investigada através de métodos quantitativo e qualitativo. A susceptibilidade à oxacilina foi determinada por métodos de difusão em discos (1 $\mu \mathrm{g})$, diluição em ágar $(0,125 \mathrm{a} 4 \mathrm{mg} / \mathrm{ml})$ e ágar screen $(6 \mu \mathrm{g} / \mathrm{ml})$. A presença do gene $m e c A$ foi pesquisada por PCR. As espécies de SCN de origem clínica mais comumente isoladas foram $S$. epidermidis, S.saprophyticus, S.hominis e S.haemolyticus. Observou-se uma freqüência similar na produção de "slime" nas amostras de origem clínica e ambiental (25/45 e 27/47, respectivamente), tendo havido concordância nos resultados obtidos pelos métodos quantitativo e qualitativo. O gene mec $A$ foi observado em todas as cepas de $S$. epidermidis, $S$. haemolyticus e $S$. hominis que foram resistentes a oxacilina pelos métodos fenotípicos, mas não foi detectado em $S$. klossii, S. equorum, S. xylosus e S. capitis. O gene também não foi detectado em duas das seis amostras de S.saprophyticus, duas das três $S$. conhii subsp. urealyticum e duas das cinco $S$. conhii subsp. conhii, as quais resultaram resistentes à oxacilina segundo a CIM. Esse gene não foi encontrado nas cepas sensíveis à oxacilina. A maioria das amostras de SCN (ambientais e clínicas) que foram produtoras de slime foram resistentes à oxacilina, o que obriga a uma deteç̧ão precisa desses microorganismos e ao controle de sua disseminação em hospitais, particularmente entre pacientes imunocomprometidos.

Palavras-chave: Estafilococos coagulase-negativo, "slime", $m e c A$, oxacilina-R.

\section{REFERENCES}

1. Arciola, C.R.; Baldassarri, L.B.; Montanaro, L. Presence of ica A and ica $D$ genes and slime production in a collection of staphylococcal strains from catheter-associated infections. J. Clin. Microbiol., 39: 2151-2156, 2001.

2. Barcs, I.; Valvinagy, T.; Panovics, J. Clinical ocurrence and virulence testing of coagulase-negative staphylococci. Acta Microbiol. Hung., 36: 415-424, 1989.

3. Brakstad, O.G.; Maeland, J.A. Mechanisms of methicillin resistance in staphylococci. APMIS., 105: 264-276, 1997.

4. Christensen, G.D.; Simpson, W.A.; Bisno, A.L.; Beachey, E.H. Adherence of slime producing strains of Staphylococcus epidermidis to smooth surfaces. Infect. Immun., 37: 318-326, 1982.

5. Christensen, G.D.; Parisi, J.T.; Bisno, A.L.; Simpson, W.A.; Beachey, E.H. Characterization of clinically significant strains of coagulasenegative staphylococci. J. Clin. Microbiol., 18: 258-259, 1983.

6. Christensen, G.D.; Simpson, W.A.; Jounger, J.J.; Baddour, L.M.; Barrett, F.F.; Melton, D.M.; Beachey, E.H. Adherence of coagulasenegative staphylococci to plastic tissue culture plates: a quantitative model for the adherence of staphylococci to medical devices. $J$. Clin. Microbiol., 22: 996-1006, 1985.

7. Davenport, D.S.; Massanari, R.M.; Pfaller, M.A.; Bale, M.J.; Streed, S.A.; Hierholzer Jr., W.J. Usefulness of a test for slime production as a marker for clinical significant infections with coagulase-negative staphylococci. J. Infect. Dis., 153: 332-339, 1986.

8. Galdbart, J.O.; Morvan, A.; Despalces, N.; El Solh, N. Phenotypic and genomic variation among Staphylococcus epidermidis strains infecting joing prostheses. J. Clin. Microbiol., 37: 1306-1312, 1999.

9. Hussain, Z.; Stoakes, L.; Massey, V.; Diagre, D.; Fitzgerald, V.; El Sayed, S.; Lannigan, R. Correlation of oxacillin MIC with mecA gene carriage in coagulase-negative staphylococci. J. Clin. Microbiol., 38: 752-754, 2000.

10. Ieven, M.; Verhoeven, J.; Pattyn, S.R.; Goossens, H. Rapid and economical method for species identification of clinical significant coagulase-negative staphylococci. J. Clin. Microbiol., 33: 10601063,1995

11. Jaffe, R.; Lane, J.D.; Albury, S.V.; Niemeyer, D.M. Rapid extraction from and direct identification in clinical samples of methicillinresistant staphylococci using the PCR. J. Clin. Microbiol., 38: 34073412,2000

12. Jarlov, J.O. Phenotypic characteristics of coagulase-negative staphylococci typing and antibiotic susceptibility. APMIS. 91: 1-42, 1999.

13. Kleeman, K.T.; Bannerman, T.L.; Kloos, W.E. Species distribution of coagulase-negative staphylococcal isolates at a community hospital and implications for selection of staphylococcal identification procedures. J. Clin. Microbiol., 31: 1318-1321, 1993.

14. Kloos, W.E.; Bannerman, T.L. Update on clinical significance of coagulase-negative staphylococci. Clin. Microbiol. Rev., 7: 117-140, 1994.

15. Kloss, W.E.; Bannerman, T.L. Staphylococcus and Micrococcus sp. p. 282-298. In: P.R. Murray, E.J. Baron, M.A. Pfaller, F.C.Tenover, and R.H.Yolkenledl.(eds.), Manual of Clinical Microbiology, $6^{\text {th }}$ ed. ASM Press, Washington, D.C. 1995.

16. Kohner, P.; Uhl, J.; Kolbert. C.; Persing, D.; Cockerill, F. Comparison of susceptibility testing methods with $m e c A$ gene analisis for determining oxacillin (methicillin) resistance in clinical isolates of Staphylococcus aureus and coagulase-negative Staphylococcus species. J. Clin. Microbiol., 37: 2952-2961, 1999.

17. Mack, D.; Rohde, H.; Dobinsky, S.; Riedewald, J.; Nedelmann, M.; Knobloch J.KM.; Elsner, H.A.; Feucht, H.H. Identification of three essential regulatory gene loci goberning expression of Staphylococcus epidermidis polysaccharide intercelular adhesin and biofilm formation. Infect. Immun., 8: 3799-3807, 2000.

18. Marinella, M.A.; Pierson, C.; Chenoweth, C. The stethoscope. A potential source of nosocomial infection? Arch. Intern. Med., 157: 786-790. 1997. 
19. Marshall, S.A.; Pfaller, M.A.; Jones, R.N. Ability of the modified vitek card to detect coagulase-negative staphylococci with mecA and oxacillin resistant phenotypes. J. Clin. Microbiol., 37: 2122 2123, 1999

20. National Committee for Clinical Laboratory Standards. Methods for dilution antimicrobial susceptibility tests for bacteria that grow aerobically. Approved standard M7-A5. Fifth edition. Wayne, USA: NCCLS, 2000.

21. National Committee for Clinical Laboratory Standards. Performance standards for antimicrobial disk susceptibility test. Approved standard M2-A7. Seventh edition. Wayne, Pa. NCCLS, 2000.

22. Neely, A.N.; Maley, M.P. Survival of enterococci and staphylococci on hospital fabrics and plastic. J. Clin. Microbiol., 38: 724-726, 2000.

23. Oto, S.; Aydin, P.; Ciftcioglu, N.; Dursun, D. Slime production by coagulase-negative staphylococci isolated in chronic blepharitis. Eur J. Ophthalmol., 8: 1-3, 1998.
24. Peters, G.R.; Locci, R.; Pulverer, G. Adherence and growth of coagulase-negative staphylococci on surface of intravenous catheters. J. Infect. Dis., 146: 479-482, 1982.

25. Peters, G. New considerations in the pathogenesis of coagulasenegative staphylococcal foreing body infection. J. Antimicrob. Chemother., 21(Suppl.C): 139-148, 1988.

26. Pfaller, M.A.; Davenport, D.; Bale, M.; Barret, M.; Koontz, F.; Massanari R. Development of the cuantitative micro-test for slime production by coagulase negative staphylococci. Eur. J. Clin. Microbiol. Infect. Dis., 7: 30-33, 1988.

27. Rupp, M.E.; Archer, G.L. Coagulase-negative staphylococci pathogens associated with medical progress. Clin. Infect. Dis., 19: 231-243, 1994

28. Wichelhaus, T.A.; Kern, S.; Schafer, V.; Brade, V. Rapid detection of epidemic strains of methicillin-resistant Staphylococcus aureus. J. Clin. Microbiol., 37: 690-693, 1999. 